\title{
Editorial
}

\section{Editorial changes}

Every two to three years PINS "renews" its Editorial group. This allows current editors to commit to staying on the journal's editorial group, or to move off to pursue other intellectual interests. This process ensures that the editorial group members who choose to stay on continue to devote some time and energy to the running of the journal. As an independent journal, with no infrastructural support, PINS relies on the "free labour" of editors to contribute to its production and continued sustainability. The editorial renewal also allows PINS to approach new people to join the editorial group.

So at the end of 2017 a few changes of the Editorial group were confirmed. Of the current editors, only Martin Terre Blanche (UNISA) wanted to move off completely. Some of the other remaining longstanding editors wanted still to be part of the PINS Editorial, but to play a lesser role. To this end a category of "consulting editors" has been created, where these editors will play mostly a supportive and advisory role for the Editorial group.

The new group of consulting editors will be: Arvin Bhana (MRC, \& UKZN); Kevin Durrheim (UKZN); Don Foster (UCT); and Kopano Ratele (MRC, \& UNISA).

During this renewal process, the current editors suggested names of new people who could be approached to join the editorial group. The following have been confirmed as new editors from the beginning of 2018: Floretta Boonzaier (UCT); Hugo Canham (Wits); Shose Kessi (UCT); Wahbie Long (UCT); Desmond Painter (US); Suntosh Pillay (UKZN, \& King Dinizulu Hospital Complex); Garth Stevens (Wits); Ross Truscott (UWC). 
These new editors, along with four of the current editors, will constitute the Editorial group from 2018. The four remaining current editors being: Ronelle Carolissen (US); Derek Hook (Duquesne University); Peace Kiguwa (Wits); Lindy Wilbraham (Rhodes).

Grahame Hayes will stay on as editor until the newly constituted editors choose someone to take over as editor. At that point Grahame Hayes will join the "consulting editors" group.

This new Editorial group is an exciting mix of experience, innovative ideas, and scholarly commitment to psychological theory and practice that is socially embedded in the society in which it operates. In their hands, the social project of PINS should be well served.

\section{Narratives of everyday resistance}

This final issue of 2017 - PINS $\mathbf{5 5}$ - is a special issue devoted to narrative research, both in its methodological innovativeness in accessing the voices of the marginalized, and as a theoretical lens that opens up the links between the local, the particular, with the global, and the general. The papers in this issue were first presented at a colloquium hosted by the transdisciplinary research network Narrative Enquiry for Social Transformation (NEST), a project supported by the National Institute for the Social Sciences and Humanities (NIHSS). This special issue on narrative is guest edited by Hugo Canham and Malose Langa.

PINS would like to acknowledge the financial contribution of NEST to the production costs of this special issue. It is through this financial contribution that PINS was able to afford the extra production of cost of colour reproductions of photographs, maps, diagrams that appear in some of the papers.

\section{Errata}

In PINS 50 (2016), the special issue on Robert Sobukwe, there were two errors in Derek Hook's article, "Sobukwe and the psychosocial". Firstly, the author Mkhize was spelt incorrectly, and secondly the two Mkhize references mentioned in the text were missing from the reference list. Here are the two references that were omitted:

Mkhize, N (2004a) Psychology: An African perspective, in Hook, D (ed) Critical psychology. Cape Town: UCT Press.

Mkhize, N (2004b) Sociocultural approaches to psychology: Dialogism and African conceptions of the self, in Hook, D (ed) Critical psychology. Cape Town: UCT Press.

Grahame Hayes 